\title{
Latin America from crisis to sustainable growth: image change and new development paradigms
}

\begin{abstract}
The aim of the article is to identify the role of Latin America in the global economy between 1990 and 2010. The analysis is based on the indicators that define social and economic potential (regional GNI, GNI per capita, growth rates, share in global production output, etc.). The article examines in detail the structural and regional shifts in Latin America's foreign trading: the share of manufactures in Latin American exports has shrunk sharply since 2000; primary commodities have become more important for the region's trade; China has become a privileged trading partner for Latin America; the region's resilience to the crisis has renewed trade interest from the EU; the USA's share in the region's trade has reduced. The analysis allowed a proposal for decision methods addressing major issues in the region's trade through the diversification of Latin American export and the intensification of intra-regional trade.

Keywords

Economic potential $\cdot$ economic growth $\cdot$ structural shifts $\cdot$ Latin America

- foreign trade $\bullet$ international economic relations
\end{abstract}

(c) University of Warsaw - Faculty of Geography and Regional Studies

\author{
Veronika N. Kholina \\ Alyona R. Massarova ${ }^{2}$ \\ ${ }^{1}$ Department of Regional Economics and \\ Geography, Faculty of Economics, \\ Peoples' Friendship University of Russia \\ e-mail: vkholina@gmail.com \\ 2Department of Regional Economics and \\ Geography, Faculty of Economics, \\ Peoples' Friendship University of Russia \\ e-mail: alyonamassarova@yandex.com \\ Received: 15 March 2013 \\ Accepted: 29 May 2013
}

Introduction

The change in the world balance of forces, which was accelerated by the global financial and economic crisis, affected international competition at the beginning of the $21^{\text {st }}$ Century. The ratio of $\mathrm{GNI}$ volume between developed and emerging countries actually reached a parity in 2010 and, excluding newly industrialized countries (the Republic of Korea, Singapore, Taiwan, Hong Kong (SAR of China) which the IMF attributes to developed countries since 1997) from the developed-countries group, it can be stated that developed economies have formally lost their leadership in the world economy.

The new economic reality underscores the formation of new world power centres that are experiencing dynamic growth and technological innovation. Latin America, with its rich natural resources, human, territorial and economic potential is a perfect example. The region's image is changing: the debt crisis, "population explosion", dependent status and military coups are in the past, and Latin America has shown high rates of socioeconomic growth and development over the last two decades.

It has been said, not without justification, that the $20^{\text {th }}$ Century did not end in 2000, but in 1989 - with the fall of the Berlin wall. This is at least partly true, inasmuch as it was a historical event that crystallized a profound change and redrew the planet's political and economic architecture.

The early 1980s were marked by the debt crisis, which coincided with a new production paradigm, underlain by the acceleration of scientific and technological knowledge, the progressive globalization of markets and communication and tougher competition that required serious internal reorganization to enable adaptation to the new realities and opportunities.
The same situation occurred after the crisis in Mexico (19941995), which former IMF Managing Director Michel Camdessus called "the $1^{\text {st }}$ crisis of the $21^{\text {st }}$ Century". The same came about after the slumps in Argentina (1995), Brazil (1998-1999) and again in Argentina (2001-2002).

Not to belittle the importance or deny the national origin of the crises, the deep region's involvement in the global integration processes with their "distortions" and instability has influenced the development of Latin America in recent decades.

Various aspects of multipolar world formation, and the role played by Latin America therein, were researched by such Russian scientists as A.V. Bobrovnikov, V.M. Davydov (2009), L.L. Klochkovsky (2010), E.M. Astakhov (2010), B.F. Martynov (2009), as well as the experts of the United Nations Economic Commission for Latin America and the Caribbean - A. Barcena, A. Prado (2010), A.A. Hoffman (2001), D. Restuksia (2009), M. Hopenhain, A. Soho (2011).

This article presents the results of the research, revealing the current position and prospects of Latin America's development as a fast-growing centre, whose world image and role are undergoing an active transformation.

\section{The economic potential of Latin America}

Though Latin America is obviously dependent on the global economy, it has almost everything needed for self-reliance: the region contains $20 \%$ of the world's natural resources, including oil $(20 \%$ of global reserves), gas $(4 \%)$, copper $(46 \%)$, iron ore $(20 \%)$, nickel $(20 \%)$, tin $(27 \%)$, silver $(47 \%)$, gold (18\%) (U.S. Geological Survey 2012). The region also possesses favourable agroclimatic resources for agricultural development. As the recent 
Table 1. Ranking list of Latin American countries by GNI growth rates*, 2010

\begin{tabular}{|c|c|c|c|c|c|}
\hline \multirow[t]{2}{*}{ № } & \multirow[t]{2}{*}{ Region/Country } & \multicolumn{2}{|c|}{ GNI growth rates } & \multirow[t]{2}{*}{ GNI, PPP (current US\$ bn) } & \multirow[t]{2}{*}{ Share in world GNI (\%) } \\
\hline & & 2010 & 2009 & & \\
\hline- & Latin America & 6.3 & -1.8 & 6576.6 & 8.6 \\
\hline 1 & Paraguay & 15.5 & -4.9 & 32.6 & 0.04 \\
\hline 2 & Peru & 11.0 & 1.4 & 271.0 & 0.36 \\
\hline 3 & Argentina & 9.6 & -0.1 & 626.5 & 0.82 \\
\hline 4 & Uruguay & 8.3 & 2.5 & 45.5 & 0.06 \\
\hline 5 & $\begin{array}{l}\text { Dominican } \\
\text { Republic }\end{array}$ & 8.2 & 3.5 & 89.2 & 0.12 \\
\hline 6 & Brazil & 7.7 & 0.1 & 2144.3 & 2.82 \\
\hline 7 & Panama & 6.6 & 3.5 & 45.9 & 0.06 \\
\hline 8 & Mexico & 5.9 & -6.3 & 1632.4 & 2.15 \\
\hline 9 & Chile & 5.1 & -0.3 & 257.4 & 0.34 \\
\hline 10 & Costa Rica & 5.0 & -1.5 & 52.6 & 0.07 \\
\hline 11 & Nicaragua & 4.5 & -3.0 & 15.4 & 0.02 \\
\hline 12 & Ecuador & 4.5 & 0.6 & 113.5 & 0.15 \\
\hline 13 & Columbia & 3.7 & 1.9 & 417.7 & 0.55 \\
\hline 14 & Bolivia & 3.4 & 2.8 & 45.8 & 0.06 \\
\hline 15 & Guatemala & 2.9 & -0.1 & 66.6 & 0.09 \\
\hline 16 & Honduras & 2.6 & -2.1 & 28.5 & 0.04 \\
\hline 17 & El Salvador & 1.5 & -4.0 & 40.0 & 0.05 \\
\hline 18 & Venezuela. RB & -1.9 & -4.5 & 347.2 & 0.46 \\
\hline 19 & Haiti & -3.7 & 2.9 & 11.2 & 0.01 \\
\hline- & World & 4.5 & -2.6 & 75978.0 & 100 \\
\hline
\end{tabular}

* Data for countries for which there exists a complete set of indicators in the source

Source: Own calculations based on (World Bank 2011)

soy boom in the Savannas of South America shows, Brazil and other countries of the region are the last agricultural frontiers for humanity (Naumov 2012). Modern high-tech industry is developing rapidly and is staffed by a well-qualified workforce.

The Latin American region comprises a large market of 33 countries ( $16 \%$ of the Earth's surface), with a regional GNI of US $\$ 6.6$ trillion, accounting for $8.6 \%$ of the global total, with $65 \%$ of the regional volume concentrated in three countries - Argentina, Brazil, Mexico. Brazil generates half of the GNI accounted for by the top three (Table 1).

According to Goldman Sachs experts, the GNI of Brazil, one of the BRICS emerging countries, will surpass that of Canada, Italy, France, Great Britain, Germany and Japan by 2038. Among other Latin American countries, Mexico is expected to achieve a similar result. By 2050, Brazil may become the world's fifth largest economy with a GNI of US\$11.4 trillion; Mexico's GNI may reach US $\$ 9.3$ trillion, Russia's - US $\$ 8.6$ trillion, Japan's - US $\$ 6.7$ trillion, Germany's - US $\$ 5.0$ trillion (Goldman Sachs 2007). Now Brazil is in $8^{\text {th }}$ place in the ranking of countries according to GNI (after the U.S., China, Japan, India, Germany, Russia, France), and Mexico is in $11^{\text {th }}$ place (coming after the above-mentioned countries, the UK and Italy) (World Bank 2011).
At the beginning of the second decade of the $21^{\text {st }}$ Century, at Davos and other specialized forums, it was forecasted that the next decade could be the decade of Latin America. The region weathered the worst international crisis of the past 80 years with unprecedented resilience and emerged from it sooner and more strongly than the developed economies. In 2010, regional GNI growth rate reached $6.3 \%$, driven by strong domestic demand in the form of both consumption and investment, and by buoyant external demand. On the domestic demand side, private consumption (up 6\%) was sustained by an upturn in employment and wages, brightening economic expectations, an increase in lending to the private sector and, in some countries, an upswing in remittances from emigrant workers (Ocampo 2011). Public consumption rose by $4 \%$ and investment jumped by $15 \%$ with strong growth in the machinery and equipment segments in particular.

However, GNI growth rates were very uneven from one country to another. The countries experiencing the highest growth rates were the members of MERCOSUR. By contrast, output contracted in Venezuela and Haiti, by $2.5 \%$ and $6.6 \%$, respectively. In the latter case, the downturn was attributable to the earthquake of January 2010, which struck a severe blow to 
MISCELLANEA GEOGRAPHICA - REGIONAL STUDIES ON DEVELOPMENT

Vol. $17 \cdot$ No. $2 \cdot 2013 \cdot$ pp. 12-19 •ISSN: 2084-6118 • DOI: 10.2478/v10288-012-0037-y

Table 2. GNI composition by sector and labour force by occupation in some Latin American countries, \%, 2010

\begin{tabular}{|c|c|c|c|c|c|c|}
\hline \multirow[t]{3}{*}{ Country } & \multicolumn{6}{|c|}{ Economic sector } \\
\hline & \multicolumn{2}{|c|}{ Agriculture } & \multicolumn{2}{|c|}{ Industry } & \multicolumn{2}{|c|}{ Services } \\
\hline & $\%$ of GNI & $\%$ of labour force & $\% \mathrm{GNI}$ & $\%$ of labour force & $\% \mathrm{GNI}$ & $\%$ of labour force \\
\hline Brazil & 5.5 & 20.0 & 27.5 & 14.0 & 67.0 & 66.0 \\
\hline Mexico & 3.7 & 13.7 & 34.0 & 23.4 & 62.2 & 62.9 \\
\hline Argentina & 9.0 & 5.0 & 26.3 & 23.0 & 64.6 & 72.0 \\
\hline $\begin{array}{l}\text { Trinidad and } \\
\text { Tobago }\end{array}$ & 0.3 & 3.8 & 58.4 & 33.2 & 41.3 & 62.9 \\
\hline Guatemala & 40.5 & 38.0 & 29.9 & 14.0 & 29.6 & 48.0 \\
\hline Panama & 4.1 & 17.0 & 16.7 & 18.6 & 81.2 & 64.4 \\
\hline Latin America & 6.2 & 14.2 & 30.1 & 22.7 & 63.6 & 62.6 \\
\hline World & 2.8 & 36.1 & 26.3 & 21.5 & 70.8 & 42.4 \\
\hline
\end{tabular}

Source: (Central Intelligence Agency 2011)

economic activity. The GNI contraction in Venezuela reflected a slash in domestic demand as a result of declining government revenues from oil exports. After five years of strong growth, a downturn in the country's economy began in late 2008, when the price of a barrel of Venezuelan oil fell below US $\$ 30$ and inflation reached $31 \%$. So, in 2010 , the growth of the consumer price index could not be halted and the year-end inflation rate again exceeded 30\% (United Nations Economic Commission for Latin America and the Caribbean 2011).

There have been significant shifts in the territorial proportions of global industry in recent decades - the ratio between the developed and emerging countries has changed. The shares of European and North American developed countries decreased, while the shares of Asia and Latin America grew. Production output in Latin America doubled between 1990 and 2010, and now the region defines $7 \%$ of global production output, the highest value in the past twenty years. The region has the same share in the global production of services and $11 \%$ in agricultural production (ahead of the North American share) (Kholina 2013).

Latin America's GNI structure altered between 1990 and 2010: the service sector increased by $10 \%$ (64\% in 2010), the share of primary and secondary sectors shrank - from $9 \%$ in 1990 to $6 \%$ in 2010 and $36 \%$ in 1990 to $30 \%$ in 2010 , respectively. Regarding the dynamics of labour force by occupation, it must be highlighted that the region's service sectors continued to enlarge their share of formal employment (rising from $57.2 \%$ to $62.6 \%$ ). By contrast, the share of formal employment in agriculture declined, from $18.8 \%$ in 1990 to $14.2 \%$ in 2010. The proportion of formal employment in industry remained nearly unchanged: $23.9 \%$ in 1990 and $22.7 \%$ in 2010. However, there are notable differences among sectors between individual Latin American countries (Table 2).

\section{The human potential of Latin America}

The population of the region reached 595 million people in 2012, accounting for $8.5 \%$ of the world total. From 1995 to 2010 , annual population growth rates in Latin America were $1.7 \%$, but within the third stage of demographic transition (a stage of modern population growth), which is characterized by a rapid decline in fertility and mortality, the population growth rate dropped to $1.1 \%$ in 2010 . At the same time, population density soared from 8 people per $1 \mathrm{~km}^{2}$ in 1950 , to 22 per $1 \mathrm{~km}^{2}$ by 1990 , and 28 people per $1 \mathrm{~km}^{2}$ in 2010 (which is higher than in North America, Australia and Oceania). However, the differences in population density are significant: from 3 people per $1 \mathrm{~km}^{2}$ (in Suriname) up to 636 people per $1 \mathrm{~km}^{2}$ (in Barbados).

Birth rate fell between 1990 and 2010, from 26\% to $18 \%$, while mortality rate was $6 \%$ in 2010 , the lowest in the world. Life expectancy increased, from 71 to 77 years for women and from 65 to 70 years for men, the highest figures among the world's emerging centres. Additionally, Latin America is the world's "youngest" region, despite the fact that the share of the population aged under 15 years decreased from $36 \%$ in 1990 to 28\% in 2010 (United Nations 2011a).

Modernization processes have positive repercussions on development, since GNI per capita and quality of life increase, with demographic indicators approaching the level of developed countries.

Latin America's GNI per capita (PPP) ranked third largest in the world (US $\$ 11,000$ in 2010) and was less than that of Europe and North America. Twenty Latin American countries are in the group of countries with high human development (Table 3).

Latin America is a largely urbanized region $(80 \%$ of the total population live in cities) and defines a $14 \%$ share of the total global urban population. High urbanization levels usually correlate with progress in social-economic development: higher income, greater access to services, and lower incidence of poverty. Latin America is no exception: today the urban poverty incidence, at $28 \%$, is half that of rural areas, and the incidence of extreme poverty, at $12 \%$, is $1 / 3$ that of rural areas. Despite this relatively low poverty incidence, the number of poor people is high. The World Bank's own estimates suggest that $60 \%$ of the poor (113 million people) and half the extreme poor (46 million people) live in urban areas (Fay 2010). The urban population increase in Latin America can be largely explained by migration of the rural poor, a process resulting in false urbanization. This causes vast areas of uncontrolled construction and an increase in informal sector activities.

\section{Shifts in Latin America's foreign trade}

In addition to the rapid economic growth and thriving living conditions, Latin America showed faster export growth than any other region in the world in 2010 . This performance is partly explained by the fact that demand in the United States and China (its two main trading partners) maintained positive growth during and after the crisis. Although export and import growth in Latin America fell sharply in 2009 , with trade turnover declining by 
Table 3. Latin American countries in the ranking list by Human Development Index, 2010

\begin{tabular}{|c|c|c|c|c|c|c|c|c|c|c|}
\hline \multirow[t]{2}{*}{ Rank } & \multirow[t]{2}{*}{ Country } & \multirow[t]{2}{*}{$\begin{array}{c}\text { Population } \\
\text { (million people) }\end{array}$} & \multicolumn{2}{|c|}{$\begin{array}{l}\text { Population } \\
\text { growth rates } \\
(\%)\end{array}$} & \multirow[t]{2}{*}{\begin{tabular}{|c|} 
Urban \\
population \\
$(\%)$
\end{tabular}} & \multirow[t]{2}{*}{$\begin{array}{c}\text { Median } \\
\text { age } \\
\text { (years) }\end{array}$} & \multirow[t]{2}{*}{$\begin{array}{l}\text { Dependency } \\
\text { ratio } \\
(\%)\end{array}$} & \multirow[t]{2}{*}{$\begin{array}{c}\text { GNI per } \\
\text { capita } \\
\text { (PPP US\$) }\end{array}$} & \multirow[t]{2}{*}{$\begin{array}{l}\text { Public expenditure } \\
\text { on education } \\
\text { (\% of GNI) }\end{array}$} & \multirow[t]{2}{*}{$\begin{array}{c}\text { Total expenditure } \\
\text { on health } \\
\text { (\% of GNI) }\end{array}$} \\
\hline & & & $1990-1995$ & $2010-2015$ & & & & & & \\
\hline \multicolumn{11}{|c|}{ Very high human development (3) } \\
\hline 44 & Chile & 17.3 & 1.8 & 0.9 & 89.2 & 32.1 & 45.4 & 14311 & 8.2 & 8.2 \\
\hline 45 & Argentina & 40.8 & 1.3 & 0.9 & 92.6 & 30.4 & 54.7 & 14538 & 9.5 & 9.5 \\
\hline 47 & Barbados & 0.3 & 0.3 & 0.2 & 45.1 & 37.5 & 40.2 & 17564 & 6.8 & 6.8 \\
\hline \multicolumn{11}{|c|}{ High human development (20), incl. } \\
\hline 48 & Uruguay & 3.4 & 0.7 & 0.3 & 92.6 & 33.7 & 56.6 & 13189 & 7.4 & 7.4 \\
\hline 57 & Mexico & 114.8 & 1.8 & 1.1 & 78.1 & 26.6 & 54.1 & 14258 & 6.5 & 6.5 \\
\hline 73 & $\begin{array}{c}\text { Venezuela. } \\
\text { RB } \\
\end{array}$ & 29.4 & 2.3 & 1.5 & 93.6 & 26.1 & 53.6 & 12323 & 6.0 & 6.0 \\
\hline 84 & Brazil & 196.7 & 1.6 & 0.8 & 86.9 & 29.1 & 47.3 & 10367 & 9.0 & 9.0 \\
\hline \multicolumn{11}{|c|}{ Medium human development (9), incl. } \\
\hline 98 & $\begin{array}{c}\text { Dominican } \\
\text { Republic }\end{array}$ & 10.1 & 1.9 & 1.2 & 69.8 & 25.1 & 58.8 & 8433 & 5.9 & 5.9 \\
\hline 107 & Paraguay & 6.6 & 2.4 & 1.7 & 62.1 & 23.1 & 62.1 & 4523 & 7.1 & 7.1 \\
\hline 131 & Guatemala & 14.8 & 2.3 & 2.5 & 49.9 & 18.9 & 83.4 & 4720 & 7.1 & 7.1 \\
\hline \multicolumn{11}{|c|}{ Low human development (1) } \\
\hline 158 & Haiti & 10.1 & 2.0 & 1.3 & 53.6 & 21.5 & 66.6 & 1151 & 6.1 & 6.1 \\
\hline
\end{tabular}

Source: (United Nations Development Programme 2011)

Table 4. Main indicators of Latin America's foreign trade, 1990-2010

\begin{tabular}{|c|c|c|c|c|c|c|c|c|}
\hline \multirow[t]{2}{*}{ Year } & \multicolumn{2}{|c|}{ Trade turnover } & \multicolumn{2}{|c|}{ Including } & \multicolumn{2}{|c|}{ Growth rates (\%) } & \multirow[t]{2}{*}{ Trade balance (US\$ bn) } & \multirow[t]{2}{*}{$\%$ of Imports } \\
\hline & US\$ bn & $\begin{array}{l}\text { Share in } \\
\text { world (\%) }\end{array}$ & $\begin{array}{l}\text { Exports } \\
\text { (US\$ bn) }\end{array}$ & $\begin{array}{l}\text { Imports } \\
\text { (US\$ bn) }\end{array}$ & Exports & Imports & & \\
\hline 1990 & 240 & 3.5 & 132 & 108 & 9.4 & 12.7 & 24 & 22.5 \\
\hline 1995 & 445 & 4.3 & 217 & 228 & 22.5 & 11.5 & -11 & -5 \\
\hline 2000 & 706 & 5.4 & 347 & 359 & 20.2 & 16.2 & -12 & -3 \\
\hline 2005 & 1054 & 5.0 & 557 & 497 & 21.5 & 18.9 & 60 & 12 \\
\hline 2007 & 1456 & 5.1 & 748 & 708 & 12.6 & 19.8 & 40 & 5.6 \\
\hline 2008 & 1734 & 5.3 & 871 & 863 & 16.4 & 21.8 & 8 & 0.9 \\
\hline 2009 & 1321 & 5.2 & 675 & 646 & -22.5 & -25.1 & 28 & 4.4 \\
\hline 2010 & 1707 & 5.6 & 860 & 847 & 27.4 & 31.0 & 13 & 1.5 \\
\hline
\end{tabular}

Source: Own calculations based on (United Nations 2011b)

$20 \%$ compared to the previous year, in 2010 the trade growth rates achieved the best indicators for the last twenty years, trade volume surpassing the level of 2008 (5.6\% of global trade volume) (Table 4).

The list of the top 50 countries that form nearly $100 \%$ of global trade includes Argentina, Brazil, Chile and Mexico, and in 2010 they defined $82 \%$ of the region's exports and $73 \%$ of the region's imports. Between 2000 and 2010 the countries' positions changed, but the most active involvement in global trade was demonstrated by Chile, which increased export and import volume by more than $60 \%$ (Table 5 ).
Latin America's foreign trade: features of commodity structure

Significant qualitative shifts took place in the export merchandise structure of Latin America. Manufactures were the major commodity group in 2010 , although their share had been declining since 2000. This happened due to the growth of other product areas, particularly fuels. In addition, there was a significant leap in "food" and "ores, metals and precious stones", which are included in the group of "primary commodities, excluding fuels". Latin America possesses 2/5 of the global copper reserves (notably in Colombia, Ecuador, Peru, Chile), and in fact 
MISCELLANEA GEOGRAPHICA - REGIONAL STUDIES ON DEVELOPMENT

Vol. $17 \cdot$ No. $2 \cdot 2013 \cdot$ pp. 12-19 •ISSN: 2084-6118 • DOI: 10.2478/v10288-012-0037-y

Table 5. Latin American countries in the list of 50 leading exporters and importers in global merchandise trade, 2000 and 2010

\begin{tabular}{|c|c|c|c|c|c|c|c|c|c|c|c|c|c|}
\hline \multicolumn{7}{|c|}{ Exports } & \multicolumn{7}{|c|}{ Imports } \\
\hline \multicolumn{2}{|c|}{ Rank } & \multirow[t]{2}{*}{ Country } & \multicolumn{2}{|c|}{$\begin{array}{l}\text { Value of exports } \\
\text { (US\$ bn) }\end{array}$} & \multicolumn{2}{|c|}{$\begin{array}{c}\text { Share in world } \\
(\%)\end{array}$} & \multicolumn{2}{|c|}{ Rank } & \multirow[t]{2}{*}{ Country } & \multicolumn{2}{|c|}{$\begin{array}{l}\text { Value of imports } \\
\text { (US\$ bn) }\end{array}$} & \multicolumn{2}{|c|}{$\begin{array}{c}\text { Share in world } \\
(\%)\end{array}$} \\
\hline 2010 & 2000 & & 2010 & 2000 & 2010 & 2000 & 2010 & 2000 & & 2010 & 2000 & 2010 & 2000 \\
\hline 15 & 13 & Mexico & 298 & 166 & 2.0 & 2.6 & 16 & 11 & Mexico & 311 & 183 & 2.0 & 2.7 \\
\hline 22 & 28 & Brazil & 202 & 55 & 1.3 & 0.9 & 20 & 23 & Brazil & 191 & 59 & 1.2 & 0.9 \\
\hline 40 & 42 & Chile & 71 & 32 & 0.5 & 0.5 & 46 & 43 & Chile & 59 & 18 & 0.4 & 0.3 \\
\hline 42 & 34 & Argentina & 68 & 26 & 0.4 & 0.4 & 48 & 42 & Argentina & 57 & 25 & 0.4 & 0.4 \\
\hline 44 & 48 & $\begin{array}{c}\text { Venezuela, } \\
\text { RB }\end{array}$ & 66 & 18 & 0.4 & 0.3 & - & 44 & $\begin{array}{c}\text { Venezuela, } \\
\text { RB }\end{array}$ & - & 16 & - & 0.2 \\
\hline
\end{tabular}

Source: Own calculations based on (World Trade Organization 2011)

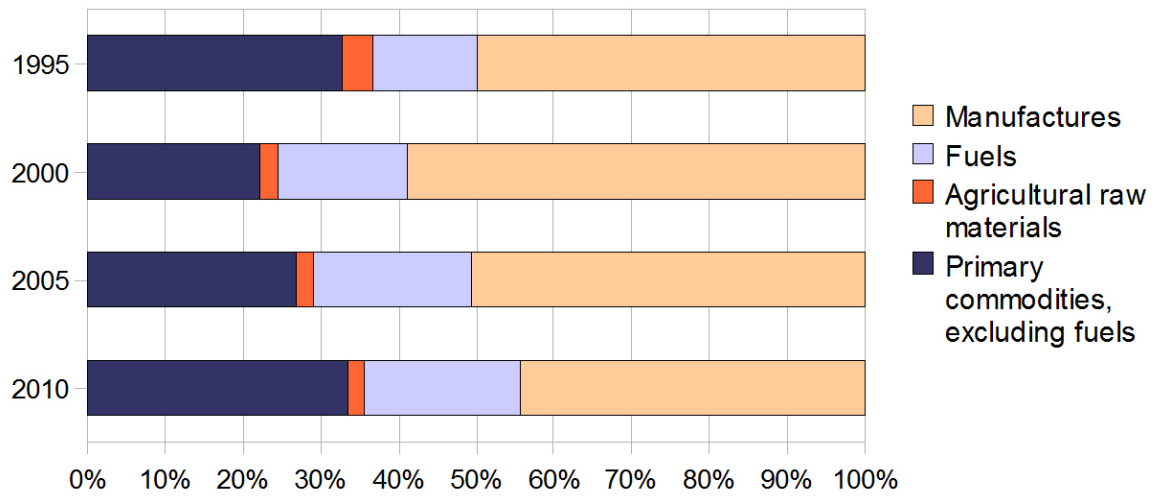

Fig. 1. Commodity structure of Latin America's exports, 1995-2010

Source: Own elaboration based on (United Nations Conference on Trade and Development, 2011)
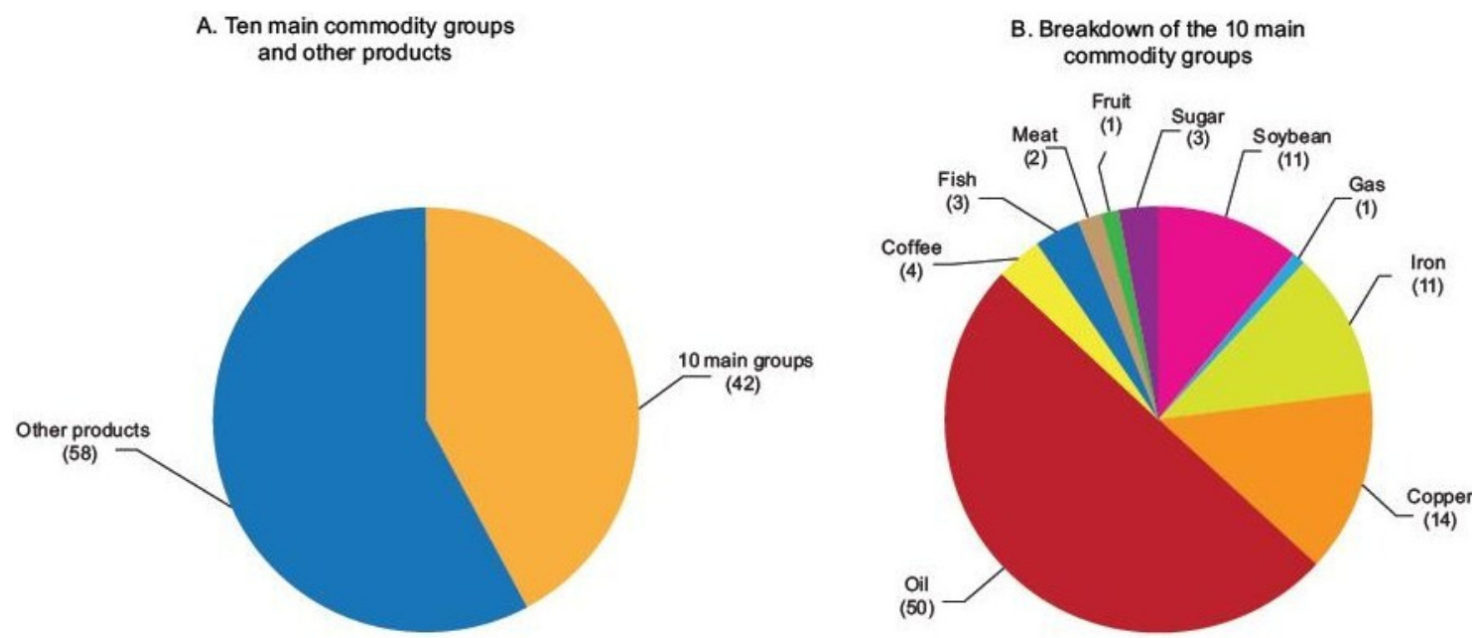

Fig. 2. Latin America: composition of total exports by main product group, \%, 2010

Source: (United Nations Economic Commission for Latin America and the Caribbean, 2011)

copper accounts for the bulk $(77 \%)$ of the group "ores, metals and precious stones" (Figure 1).

The ten main product groups exported by the region account for $42 \%$ of the region's total exports. More than $50 \%$ of the volume of the ten major products is defined by oil, besides which significant shares are found in soybean, iron and steel, and copper (Figure 2).
The bias towards the export of primary commodities in the region presents both challenges and opportunities. According to an ECLAC forecast, the price index for all 10 product groups will fall by an annual average of around 2-5\% between 2013 and 2015 , and this will ease currency appreciation pressures and pave the way for boosting exports of more complex products (including natural-resource-based products). Nonetheless, this process 
Table 6. Share of Latin America in global exports by major product group, 1990-2010

\begin{tabular}{|c|c|c|c|c|c|c|}
\hline \multirow{2}{*}{ Product group } & \multicolumn{2}{|c|}{1990} & \multicolumn{3}{c|}{2010} \\
\cline { 2 - 7 } & $\begin{array}{c}\text { US\$ } \\
\text { billion }\end{array}$ & $\begin{array}{c}\text { Share in total } \\
\text { exports (\%) }\end{array}$ & $\begin{array}{c}\text { US\$ } \\
\text { billion }\end{array}$ & $\begin{array}{c}\text { Share in total } \\
\text { exports (\%) }\end{array}$ & $\begin{array}{c}\text { US\$ } \\
\text { billion }\end{array}$ & $\begin{array}{c}\text { Share in total } \\
\text { exports }(\%)\end{array}$ \\
\hline Agricultural products & $\mathbf{3 5}$ & $\mathbf{8 . 3}$ & $\mathbf{6 1}$ & $\mathbf{1 1 . 1}$ & $\mathbf{1 8 0}$ & $\mathbf{1 3 . 2}$ \\
\hline Fuels and mining products, incl. & $\mathbf{4 6}$ & $\mathbf{9 . 5}$ & $\mathbf{8 5}$ & $\mathbf{1 0 . 0}$ & $\mathbf{2 9 0}$ & $\mathbf{9 . 7}$ \\
\hline Fuel & 32 & 8.8 & 63 & 9.6 & 175 & $\mathbf{7 . 6}$ \\
\hline Manufactures, incl. & $\mathbf{5 5}$ & $\mathbf{2 . 3}$ & $\mathbf{2 0 9}$ & $\mathbf{4 . 5}$ & $\mathbf{2 7 8}$ & $\mathbf{3 . 8}$ \\
\hline Iron and steel & 6 & 5.8 & 8 & 5.7 & 19 & 4.5 \\
\hline Chemicals & 6 & 2.1 & 16 & 2.8 & 46 & 2.7 \\
\hline Office and telecom equipment & 5 & 1.8 & 38 & 4.0 & 66 & 4.1 \\
\hline Automotive products & 7 & 2.1 & 38 & 6.7 & 78 & 7.2 \\
\hline Textile & 2 & 2.2 & 5 & 3.0 & 6 & 2.3 \\
\hline Clothing & 3 & 2.9 & 18 & 9.0 & 16 & 4.5 \\
\hline
\end{tabular}

Source: Own calculations based on (World Trade Organization 2011)

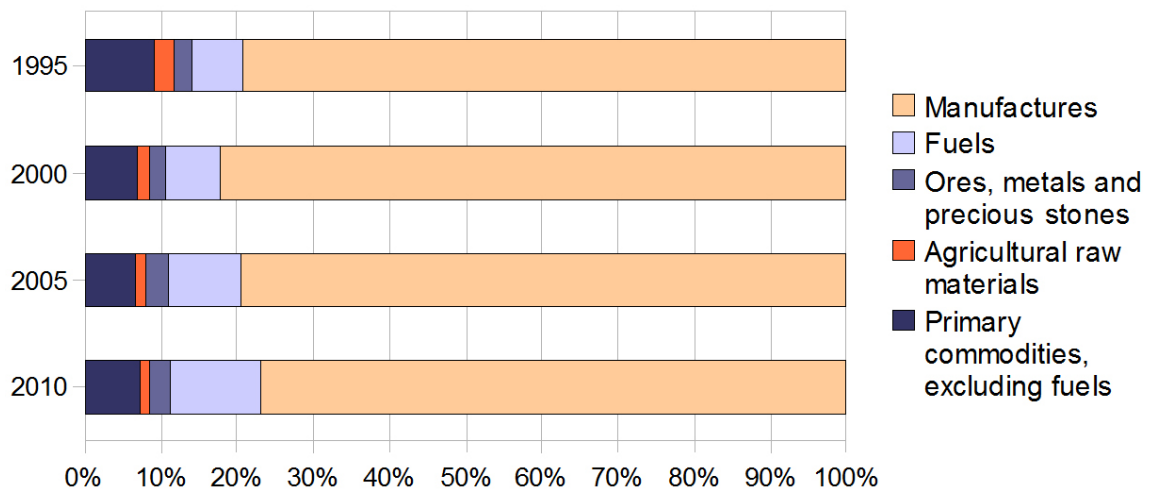

Fig. 3. Commodity structure of Latin America's imports, 1995-2010

Source: Own elaboration based on (United Nations Conference on Trade and Development, 2011)

is not automatic and poses a number of challenges for public policy that should be addressed, aiming towards the following goals: 1) promoting corporate innovation, competitiveness and internationalization, and a greater presence in broader production chains at the national, regional or international levels; 2) incorporating SMEs into the export production process; 3) strengthening intraregional trade links, since intraregional trade is more intensive in processed natural-resource-based products and industrial products (such as foods, beverages and tobacco, textile products and chemicals); 4) building better quality trade relations with China and the Asia-Pacific region, so as to boost mutual cooperation in innovation through the development of long-term partnerships that will ensure price stability (United Nations Economic Commission for Latin America and the Caribbean 2012).

The role of Latin America in the global export of various product groups reflects the bias towards primary commodities. The region's share in the global export of finished and semifinished products had dropped by 2010 , while shares in the global export of mining and fuels also decreased, though between 1990 and 2000 Latin America's participation in the global export of these product groups had risen. The period 1990 to 2010 was marked by a steady increase of Latin America's importance in the global export of one group alone: agricultural products (Table 6).

Latin American merchandise import rates did not vary significantly between 1990 and 2010 . The share of manufactures was close to $80 \%$ of the region's imports from 2000 to 2005 , narrowing to $76 \%$ by 2010 . However, this incidence is likely temporary, relating to the overall instability of the global economy. The share of primary commodities (excluding fuels) hovered around $10 \%$ of the region's imports during the last decade. The share of agricultural raw materials declined to $1.2 \%$ in 2010 , share of fuels increased sharply (almost doubling) between 2000 and 2010 (up to $12 \%$ of imports) and cost of fuels increased seven-fold (Figure 3).

Latin America's foreign trade: features of regional structure

The region's resilience to, and strong recovery from, the international financial crisis have renewed the interest of the European Union in strengthening ties. This interest is evidenced by the recently concluded association agreements with Central America, Colombia and Peru. These come in addition to existing accords with Mexico and Chile, and the re-launch of negotiations for a similar agreement with MERCOSUR (United Nations Economic Commission for Latin America and the Caribbean 2012). 
At the same time, the Asia-Pacific region — particularly China - has become a privileged trading partner for Latin America. By 2050, China may replace the European Union as the region's second largest trading partner. Latin American exports to China rose 31-fold and imports from China increased 60-fold; now the Asian economic giant receives $8 \%$ of all Latin American exports and provides $9 \%$ of the region's total imports (United Nations 2011b).

Taking into account the large proportion of primary commodities in Latin American exports to China, if the Chinese economy continues to grow at a rate of $7-8 \%$ (as suggested), the region will be guaranteed an annual growth of $16 \%$ (by volume) in its exports to China. To secure their supplies of raw materials, Chinese buyers commonly sign medium- and long-term contracts, particularly for metals (such as copper, nickel and iron ore, as the main inputs for the steel, construction and machinery industries in China). This means that Chinese buyers could well take advantage of lower commodity prices to stockpile supplies (especially of metals, soybean and other grains), as occurred during the 2008-2009 crisis (United Nations Economic Commission for Latin America and the Caribbean 2012).

Trade turnover with Africa, the Middle East and other Asian emerging markets is soaring too and, as a consequence, trade between developing nations (South-South trade) may become relatively more important for Latin America.

In this context of special opportunities and diversification of trading partners, the share of the United States of America in the region's trade has been shrinking. More importantly, there is a perception that the United States lacks strategic vision visa-vis the region. In the 1990s the Initiative for the Americas substantially increased the dynamics of trade relations between the U.S. and Latin America. In 1991 the U.S. signed free trade area framework agreements with almost all existing sub-regional groups: the Caribbean Common Market (CARICOM), the Central American Common Market, the Andean Pact, the Common Market of the Southern Cone. The U.S. and Canada entered into negotiations on the establishment of the North American Free Trade Agreement (NAFTA) with Mexico in 1991. But today no such initiatives exist.

Against this background, its share of the region's imports dropped from $51 \%$ in 2000 to $33 \%$ in 2010 ; and as a destination market for the region's exports, its share fell from $60 \%$ to $39 \%$ during the same period (United Nations 2011b).

U.S. President Barack Obama announced the intention to "create new alliances for progress in the Americas" during his fourth visit to Latin America in 2011, the year of the $50^{\text {th }}$ anniversary of John F. Kennedy's proclamation of the Alliance for Progress (1961). Now is the time for the U.S. to revitalize hemispheric relations but they must simultaneously adapt to the rapidly changing economic climate of the region.

Intra-regional trade is becoming increasingly important for Latin America: in 2010, $17 \%$ of exports and $25 \%$ of imports was realized within the region. In contrast, in the early 2000s, when there was a focus on the region's trade with the U.S., the share of intra-regional exports and imports fell to $15 \%$. On the intra-regional level the following trend is marked: Latin American countries buy the products of the region's largest economies, which in turn import commodities from the powerful countries of the global economy.

\section{Conclusions}

Latin America entered the new decade (2010) with a promising outlook for growth and advances in quality of life. During the previous decade (2000-2010), for the first time in its history, the region achieved a combination of high growth, macroeconomic stability, poverty reduction and improvement in income distribution. The image of Latin American countries is changing, and now there are several high-growth states among them, which are expected to be world leaders soon. The region showed high sustainability during the crisis in 2008 and today will be called upon to assume an increasingly larger role in the global economy. However, there is a need to aspire towards a higher level of trade between Latin America and the rest of the world, enabling economic relations to flourish. After all, significant challenges remain. Latin America is still the region with the highest levels of inequality in the world and there are serious deficiencies in technology, innovation and competitiveness. But the region and its main partners are approaching these challenges as opportunities for growth, investment and trade with a view to opening the way for new business opportunities and partnerships.

\section{References}

Astakhov, EM 2010, 'Future role and prospects for the development of Latin America in the world', Vestnik MGIMO - University, no. 4, pp. 32-37.

Bárcena, A \& Prado, A 2010, La hora de la igualdad: brechas por cerrar, caminos por abrir, CEPAL, Santiago. Available from: Libras institucionales. [15 December 2012].

Bobrovnikov, AV \& Davydov, VM 2009, The role of the rising giants in world politics (the chances of Brazil and Mexico in the global dimension), Institute of Latin America, Russian Academy of Sciences, Moscow.

Fay M (ed.) 2010, Directions in development: The Urban Poor in Latin America, The World Bank, Washington. Available from: Directions in development. [29 October 2012].

Goldman \& Sachs 2007, BRIC'S and Beyond. Available from: <http://www.goldmansachs.com/our-thinking/topics/brics/ brics-and-beyond-book-pdfs/brics-full-book.pdf>. [30 October 2012].

Hoffman, AA 2001, Long run economic development in Latin America in a comparative perspective: proximate and ultimate causes, CEPAL, Santiago. Available from: Serie Macroeconomía del desarrollo. [5 December 2012].

Hopenhain, AA \& Soho, A 2011, Sentido de pertenencia en sociedades fragmentadas. América Latina desde una perspectiva global, CEPAL, Siglo XXI, Argentina. Available from: Copublicaciones. [10 January 2013].

Kholina, V 2013, 'La Russie et France sur le marche alimentaire modial, tendances et perspectives', in La Russie, L'Europe et la Mediterranee dans la crise, Paris, L' Hartman, 2013, pp. 245-255.

Klochkovsky, LL 2010, 'Latin America in the modern world. Alignment of main forces and Prospects', Latin America, no. 11 , pp. 31-49.

Martynov, BF 2009, 'Latin America and the dilemma of a multipolar world', Latin Americ, no. 10, pp. 4-25.

Naumov, AS, Oliveira, RP, Prado, RB \& Turetta, AP 2012, 'Balanced fertilization for sustainable development of agriculture in the savannas of South America: towards a geographical approach' in Geography, Environment, Sustainability, vol. 05, no 4, pp. 84-95.

Ocampo, JA 2011, 'Macroeconomy for development: countercyclical policies and production sector transformation' in Revista de la CEPAL \#104, ed O Sunkel, CEPAL, Santiago pp. 7-35. Available from: Revista CEPAL. [19 December 2012]. 
Restuksia, D 2009, The Latin America development problem, CEPAL, Santiago. Available from: Serie Macroeconomía del desarrollo. [5 December 2012].

United Nations 2011a, World Population Prospects. Available from: <http://esa.un.org/unpd/wpp>. [22 December 2012].

United Nations 2011b, Conference on Trade and Development. Available from: <http://unctadstat.unctad.org>. [22 December 2012].

United Nations Economic Commission for Latin America and the Caribbean 2011, Economic Survey of Latin America and Caribbean: international integration and macroeconomic policy challenges amid global economic turmoil. Available from: <http://www.eclac.cl>. [20 December 2012].
United Nations Economic Commission for Latin America and the Caribbean 2012, Economic Survey of Latin America and Caribbean: policies for an adverse international economy. Available from: <http://www.eclac.cl>. [4 February 2013].

U.S. Geological Survey 2012, Commodity Statistics and Information. Available from: <http://minerals.usgs.gov/ minerals/pubs/commodity>. [28 October 2012].

World Bank 2011, World Development Indicators \& Global Development Finance. Available from: <http://databank. worldbank.org> [30 October 2012]. 